\title{
Challenges and fundamental skills for primary school teachers: Developing self-efficacy beliefs scale
}

\author{
İsmail Sarikaya \\ Bayburt University, Education Faculty, Department of Primary Education, Bayburt, Turkey, \\ ismailsarikaya@bayburt.edu.tr \\ Yavuz Sökmen ${ }^{\mathbb{D}}$ \\ Atatürk University, Kazım Karabekir Education Faculty, Department of Primary Education, Erzurum, Turkey, \\ yavuzsokmen@atauni.edu.tr
}

\begin{abstract}
The study aims to shed light on the strengths of the primary school teaching profession and the fundamental skills that a primary school teacher (PST) should have while also taking into account the views of the PSTs. However, based on the data collected, the objective is to develop a self-efficacy belief scale (SEBS) for PSTs and teacher candidates. The first stage was carried out with 80 PSTs with at least five years of professional experience. 763 PSTs and PST candidates participated in second stage of the study. A SEBS was developed for PSTs and teacher candidates in light of the obtained data. Descriptive analysis and content analysis were used for qualitative data. The categories of being a teacher in village school, administration-colleague and parent-related problems, student self-care, pedagogical qualifications, and personal and professional development were attained concerning the challenges and fundamental skills for PSTs. Scale development steps were followed second stage of the study. The SEBS containing three sub-dimensions and 19 items is assumed to be helpful and valid and reliable
\end{abstract} metrics.

\section{Sınıf öğretmenleri için zorluklar ve temel beceriler: Öz-yeterlik inanç ölçeğinin geliştirilmesi}

ÖZ Bu çalışmanın amacı sınıf öğretmenliği mesleğinin güç yönlerini ve bir sınıf öğretmeninde bulunması gereken temel becerileri, sınıf öğretmenlerinin görüşleri doğrultusunda açığa çıkarmaktır. Bununla birlikte elde edilen verilerden hareketle sınıf öğretmenleri ve öğretmen adayları için öz-yeterlik inanç ölçeğinin geliştirilmesi amaçlanmaktadır. Çalışmada nitel yöntemler ve nicel yöntemler birlikte kullanılmıştır. Çalışma iki aşamada gerçekleştirilmiştir. İlk aşama az beş yıllık mesleki deneyime sahip 80 sınıf öğretmeni ile birlikte yürütülmüştür. Çalışmanın ikinci aşamasına ise toplam 763 sınıf öğretmeni ve sınıf öğretmeni adayı katılmıștır. Elde edilen verilerle sınıf öğretmeni ve öğretmen adayları için özyeterlik inanç ölçeği geliştirilmiştir. Nitel verilerin analizinde betimsel ve içerik analizinden yararlanılmıştır. Sınıf öğretmenleri için zorluklar ve temel becerilerle ilişkili olarak köy okulunda öğretmen olmak, yönetim-meslektaş ve veli kaynaklı problemler, öğrenci öz-bakımı, pedagojik beceriler ile kişisel ve mesleki gelişim kategorilerine ulaşılmıştır. Çalışmanın ikinci aşamasında ise ölçek geliştirme adımları izlenmiştir. Üç alt boyuttan ve 19 maddeden oluşan öz-yeterlik ölçeğinin kullanışlı olduğu ve geçerli ve güvenilir ölçümler sunacağı düşünülmektedir.

Anahtar

Ö̆gretmenlik mesleği, Ölçek geliştirme, Öz-yeterlik inancı, Sinıf öğretmenleri 


\section{INTRODUCTION}

\section{Self-Efficacy}

The self-efficacy structure was introduced by Bandura (1977) firstly. Many research on self-efficacy, a motivational factor, have been performed since then (Klassen, 2002). Furthermore, according to Google Scholar, self-efficacy is the most researched and cited term in psychology (Livintii et al., 2021). With social cognitive theory, Bandura theorized that people's beliefs about their abilities and the implications of their occupations have a huge impact on their behavior patterns (Usher \& Pajares, 2008). Self-efficacy is described by Bandura (1997) as the expectation that an individual will perform an activity successfully. Two types of expectations, namely outcome expectations and self-efficacy expectations, have strong effects on the actions of individuals, according to the self-efficacy theory (Maddux et al., 1982). In fact, the most important factor affecting the behaviors of people is self-efficacy perception (Schunk, 1985).

Bandura (1997) addresses four sources in the formation of SEBs. These resources include (i) vicarious experience, (ii) mastery experiences, (iii) verbal persuasions, and (iv) affective and physiological states. The most effective one among these is mastery experience (Malinen et al., 2013; Pajares, 2003). While teacher behaviors are influenced by these sources, teacher SEBs can also impact student characteristics, according to Ross et al. (1996). Individual experiences are described as mastery experiences by Bandura (1997), and individuals' capacities which are evaluated by looking at other people's experiences are described as vicarious experiences. Bandura (1997) regarded words spoken to reinforce an individual's belief in their ability to succeed as verbal persuasions, and he articulated people's physiological and emotional states as physiological and affective states, sometimes reflecting on their physical conditions.

We see that different scales have been developed in the literature on self-efficacy (Chan, 2008; Chen et al., 2001; Chesney et al., 2006; Erdem \& Demirel, 2007; Maddux et al., 1982). We also see that the development of various self-efficacy scale to measure different fields and variables in Turkey (Akçöltekin, 2019; Akkoyunlu et al., 2005; Cantürk-Günhan \& Başer, 2007; Özgen \& Bayram, 2019; Özgen \& Bindak, 2008). It is also known that the different scales of self-efficacy have been adapted to Turkish (Aypay, 2010; Çapa et al., 2005; Öncü, 2012). However, most of the researchers were interested in the general dimension of self-efficacy. To put it in this way, studies have been carried out in general self-efficacy (Aypay, 2010).

Although there are self-efficacy scales developed or adapted in this study, it particularly stands out by addressing the primary school teachers' SEBs in Turkey. Besides, there is no agreed method on how to create teacher self-efficacy scales (Skaalvik \& Skaalvik, 2010). In this respect, this study is expected to contribute to the relevant literature. Furthermore, according to Berg and Smith (2016), one of the difficulties that researchers can face is how SEBs may vary across cultures. Also, this refers to the fact that the current scale is likely to be used in self-efficacy studies conducted in Turkey.

\section{Teacher Self-Efficacy (TSE)}

TSE, similar to self-efficacy, has received a great deal of coverage in the last two decades (Skaalvik \& Skaalvik, 2007). It is believed that the views of teachers on efficacy influence not only their enthusiasm and performance but also the performance of their pupils (Morris et al., 2017). Self-efficacy of teachers is the beliefs of teachers on how successful their skills are in the learning of their students (Klassen \& Chiu, 2010). According to Bandura (1997), teachers' self-efficacy has an effect on student achievement and motivation. Teachers with low self-efficacy, on the other hand, could have more difficulties in the classroom, according to Betoret (2006). Huang et al. (2019) found that TSE has a positive impact on teacher well-being in their research. Furthermore, TSE is a significant motivator that influences teacher 
activity (Pendergast et al., 2011). Besides, Tschannen-Moran and Woolfolk Hoy (2001) described teacher self-efficacy as "the ability to bring difficult learners or low motivation students to a level of learning." Moreover, Gibson and Dembo (1984) deemed these beliefs as teacher SEBs considering how effective they can be on student behaviors and learning outcomes. Furthermore, it has been shown in both theoretical and empirical research that TSE has a variety of effects on classroom ecology (Zee \& Koomen, 2016). From all of these, TSE can be described as teachers' confidence in their own ability to prepare, coordinate, and conduct the required activities to meet the educational objectives (Skaalvik \& Skaalvik, 2007).

Different studies with different variables on TSE have been performed in the area of interest (Caprara et al., 2006; Dellinger et al., 2008; Holzberger et al., 2013; Kim, 2011; Klassen \& Tze, 2014; Martin et al., 2008; Tuchman \& Isaacs, 2011; Zee \& Koomen, 2016). Also, a bibliometric analysis of the results gathered by entering the related keywords in the Web of Science was undertaken in order to examine studies of self-efficacy on primary school teachers from a general perspective. The keywords "selfefficacy" or "self-efficacy" and "primary school teacher" or "primary school teachers" were entered in the Web of Science database. Thus, a bibliometric analysis was conducted for 421 articles published in the field of education.

The analysis showed that the most frequently used keywords in the articles are self-efficacy $(f=76)$, primary school $(\mathrm{f}=29)$, and teacher self-efficacy $(\mathrm{f}=23)$. The map created for the most keywords used in the articles is shown in Figure 1. Also, the results of co-citation analysis for the most cited authors in the articles are shown in Figure 2. According to the co-citation analysis, the most cited authors were Bandura ( $f=468)$, Tschannen-Moran $(f=232)$, Pajares ( $f=90)$, Klassen $(f=85)$, Skaalvik $(f=83)$, and Schunk $(f=79)$. It is not surprising that the most cited author was Bandura. As we can see, his contribution to the concept of self-efficacy is noteworthy. It is understood that the most-cited journal is the journal of Teaching and Teacher Education $(f=1071)$. The map created for the most cited journals is shown in Figure 3.

\section{Figure 1.}

Most Cited Keywords

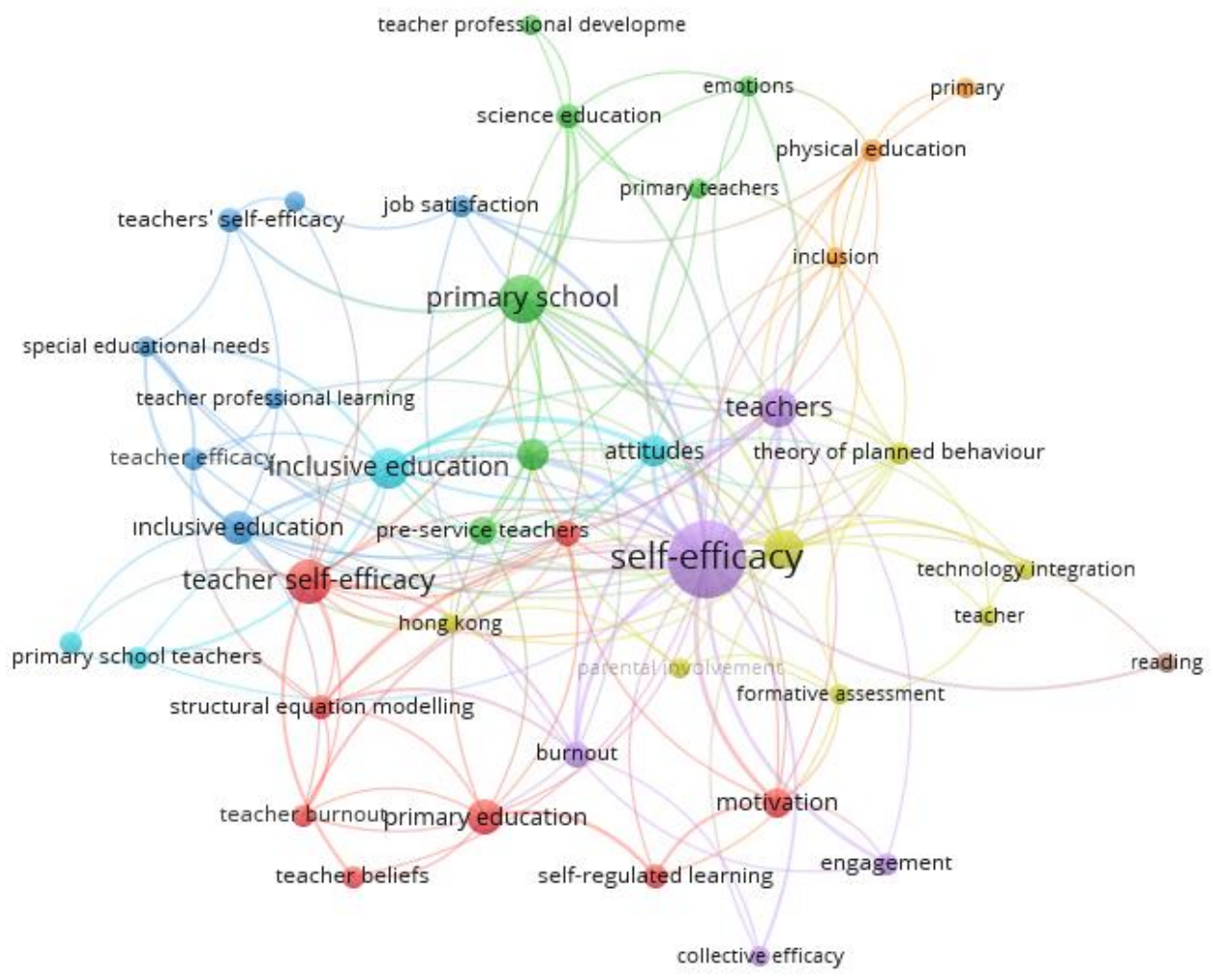


Figure 2.

Co-Citation Analysis for Most Cited Authors

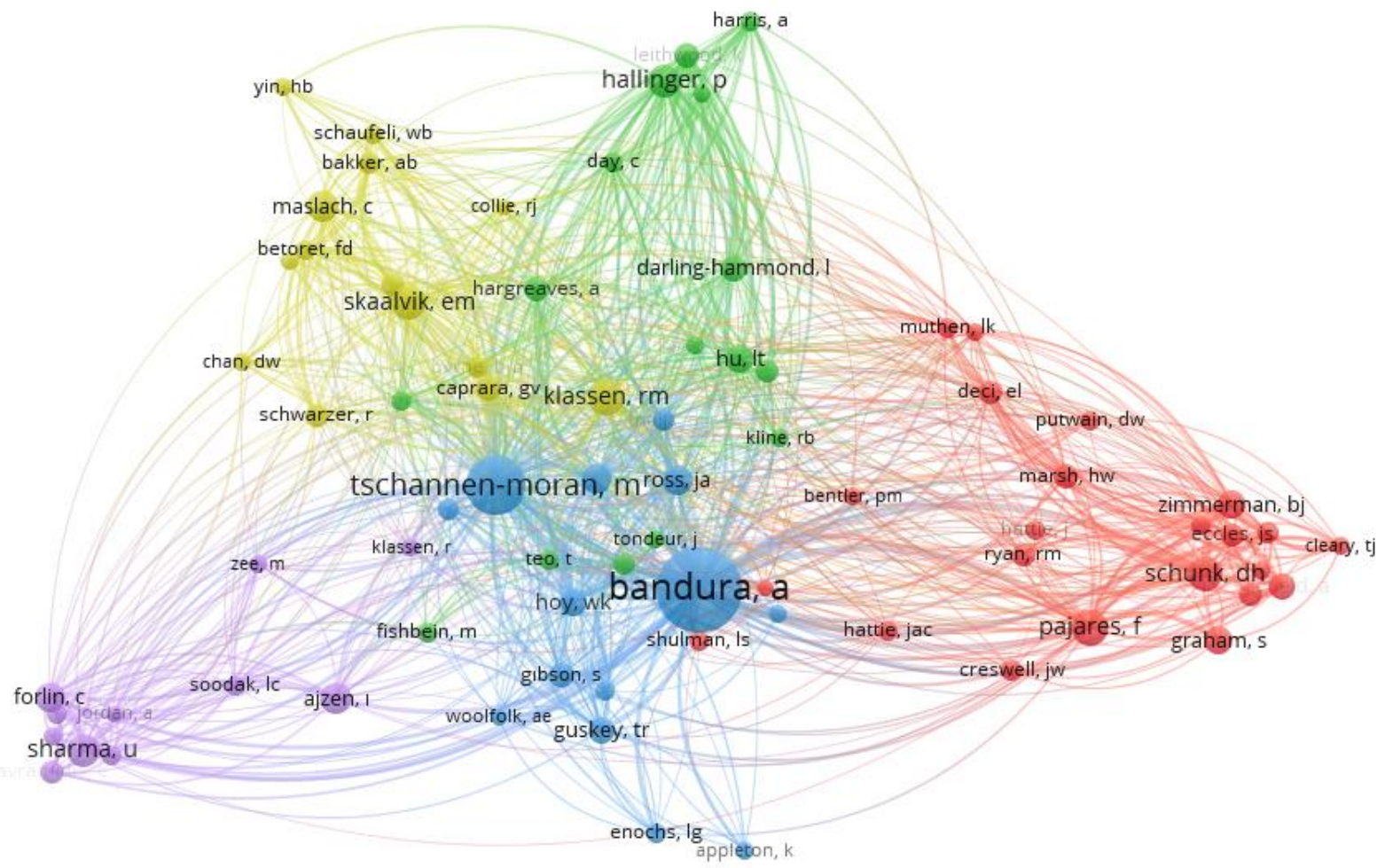

Figure 3.

Most Cited Journals

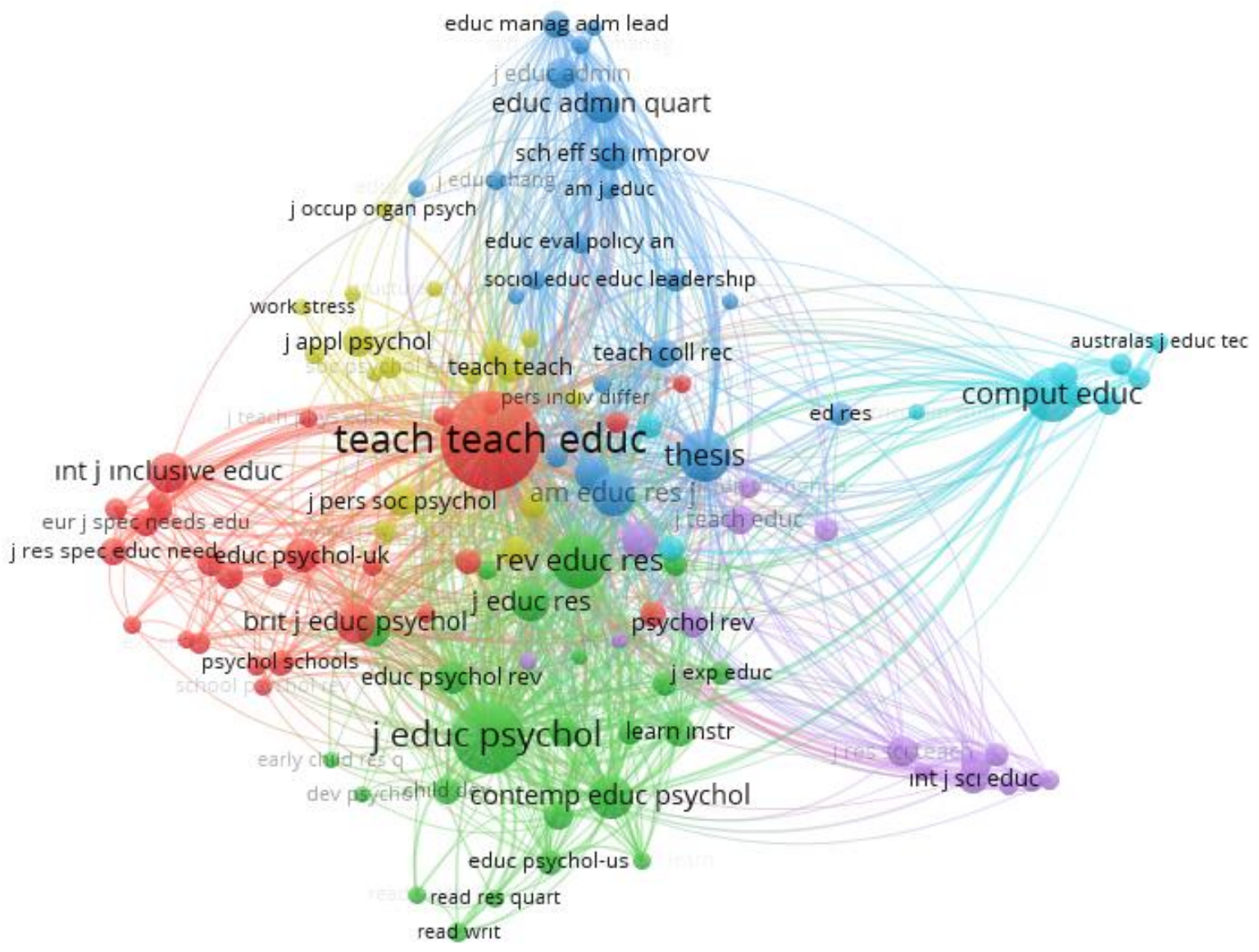


The study aims to reveal why the primary school teaching profession is challenging and what are the fundamental skills that a primary school teacher should have while also taking into account the primary school teachers' views. At the same time, the study aims to develop a SEBs scale to determine the SEBs of primary school teachers and teacher candidates from the data obtained based on the opinions of primary school teachers.

\section{METHOD}

This section contains information on the methodology of the study. Since the study was carried out in two fundamental stages, the information regarding both stages was presented under separate headings. In this study, the researchers are participant observers.

\section{Research Model}

In this research, qualitative and quantitative research methods were used. This study was carried out by following the stages of the exploratory sequential pattern, one of the fundamental patterns of mixed research methods. Qualitative data on the research question were obtained and analyzed at the first stage of the exploratory sequential design. In the second stage, a measurement tool is developed as per the analyzed qualitative data. In the last stage, data are collected yet again with the measurement tool developed (Creswell, 2014). In other words, firstly, qualitative data about why primary school teaching is a difficult profession and which fundamental skills that a primary school teacher should have were collected and analyzed. In the second part of the study, the scale development stages were followed, and then, an item pool was created based on qualitative findings. Benefiting from the literature, the item pool was enriched. The initial scale form obtained was applied to PSTs and PST candidates in two different steps, and validation and reliability analysis of the SEBS for PSTs were then completed.

\section{Participants}

Information about the participants of the study is presented under two separate headings.

\section{Study 1}

Study 1 was completed with 80 primary school teachers with at least 5 years of professional experience. The participants were determined according to one of the purposeful sampling methods, which is the criterion sampling method. The criteria here is that the teachers in the primary school have at least 5 years of experience in their field and have served in a multi-grade classroom (united) in a village school. The explanation behind these criteria is to ensure that the participants have an acceptable level of teaching experience in the classroom and they can have an insight into the challenges of being a teacher in multi-grade classrooms in a village school. Of the participants, $24(30 \%)$ of them are female while 56 $(70 \%)$ of them are male. Of the participants, 23 (28.8\%) of them have professional experience between $5-10$ years; 20 (25\%) of them between have $10-15$ years; 22 of them (27.5\%) have 15 -20 years while 15 of them $(18.7 \%)$ have 20 years or more professional experience. All participants are serving in schools affiliated with the Ministry of National Education of the Republic of Turkey and have multigrade classroom teaching experience. Of the male participants, 25 (31.3\%) were principal authorized teachers while $7(8.8 \%)$ of the female participants were principal-authorized teachers. The pseudonyms for participants are named as $\mathrm{T} 1,2, \ldots \mathrm{n}$. For example, T24 pseudonymous specifies the primary school teacher number 24.

\section{Study 2}

The data of Study 2 were collected from a total of 763 PSTs and PST candidates. The prepared draft 
scale form was first implemented to 501 PST candidates and exploratory factor analysis (EFA) was carried out. Of teacher candidates, 346 (69.1\%) participants are female while 155 (30.9) of them are male. The age of the participants ranges from 21 to 26 . All of the participants study at a state university and are Turkish. Then, to check the goodness of fit of the obtained structure, the scale was applied to a total of 262 PSTs including 168 (64.1\%) female and 94 (35.9\%) male, and confirmatory factor analysis (CFA) was performed with at least 5 years of professional experience. The age of the PSTs ranges from 29 to 51. All PSTs are serving in schools affiliated with the Ministry of National Education of the Republic of Turkey. Regarding the sample size in factor analysis efforts, Field (2013) states that working with 100 people is poor, with 200 people is fair, with 300 people is good, with 500 people is very good while working with 1000 people is excellent. Provided that the study was performed on a total sample of 763 individuals, it can be claimed that the sample size was very good. Participants are senior class students in the primary school teaching undergraduate program.

\section{Data Collection Tools and Process}

The data for Study 1 were obtained from interviews performed with primary school teachers. A semistructured interview form was used for data collection. Five scholars who are experts in primary school education provided their opinion on the draft interview form prepared by the researchers based on the literature. Certain new questions and probing questions were added to the form as a result of the feedback received from the experts. To determine whether the questions are understandable or not and also to get their feedback, the draft form was sent to three primary school teachers. Following the input of primary school teachers, the structure of certain questions was altered and a new interview question was introduced to the form. The form was presented to five faculty members with this new version. Experts stated that the form is appropriate. In the form, questions such as "Have you had an unforgettable experience? Can you share this experience?", "What are the difficulties of being a primary school teacher?", "What should be the fundamental qualifications a primary school teacher should have?". The interviews were carried out by appointment. The interviews were recorded with a tape recorder and transcribed after receiving the permission of the participants. The duration of the interviews varies between 10 and 24 minutes.

Scale development stages were followed in Study 2. A pool of 45 items was created based on the findings of Study 1 and the item samples gathered from the literature review. The steps of writing the items belonging to the measurement tool, receiving expert opinions, and conducting a pre-trial were followed while making preparations for the trial form (Tavşanc1l, 2014). To provide scope and face validity, it is recommended to seek expert opinion before the trial application (Kline, 1994). A form containing the acceptable/unacceptable options was designed for each item in order to assess the views of the experts on the compatibility of the items. The scale form was submitted for review by a total of seven expert faculty members, one of them is an measurement and evaluation expert, two of whom are expert in the field of Turkish education, two of whom are in the field of educational psychology, and two of whom are in the field of primary education. The items were assessed based on the titles namely being able to assess the teacher's SEBs, understandability of the item, and its language appropriateness. Moreover, for the items that experts want to add to the form, a section is designated. Content validity was determined as the ratio of the number of experts sharing their views as acceptable concerning items to the one minus of the total number of experts (Veneziano \& Hooper, 1997). The items that have content validity value under .80 were excluded from the scale form. The desired corrections were made in terms of scope and appearance, and the scale was finalized. As a result of these processes, 15 items were removed from the scale form and a 30-item form was finalized for item analysis. To determine the level of agreement with the items in the scale form, a 5-point Likert response category was used. The scale was applied to 20 teacher candidates in this form and tested in terms of understandability. Then, two items were revised in line with the suggestions and it was presented to two Turkish education experts again. The draft form was first applied to a group of teacher candidates and EFA was performed. Then, in order to test the suitability of the existing structure, the form was applied to 262 PSTs and the CFA was performed yet again. The reliability and validity analyzes of the scale were completed. 


\section{Data Analysis}

Data analysis is presented under separate headings for both stages.

\section{Study 1}

First, voice recordings were transcribed and digitalized, and then, page and line numbers have been added to the documents. In the data analysis of Study 1, descriptive analysis and content analysis were used. In the descriptive analysis part, the frequency values of the data are presented and if deemed necessary, direct quotations have been provided. Dey's (1993) content analysis method was used in content analysis. Firstly, the codes were defined based on the transcribed results, and then these codes were combined into suitable categories. Approximately half of the data set was re-coded by a faculty member from primary school education, and the inter-coder reliability was tested using the Cohen Kappa formula. The inter-coder reliability index is calculated as .88. Miles and Huberman (1994) states that the inter-coder reliability is sufficient when this value is .80 and above. The consensus was taken as a basis for coding, and accordingly, necessary changes were made in some codes. During the coding process, for codes that were not well understood or remained unclear, correspondence was formed with the participating teachers, and the needed confirmation was received.

Content analysis is the compilation and presentation of data under specified concepts and themes in a manner that the reader can understand (Y1ldırım \& Şimşek, 2013). First of all, the analysis unit should be determined (Merriam, 2009). Then the codes are determined. During the identification of codes and categories, the literature or message items received from the participants may be used or both approaches may be used together (Henry \& Moscovici, 1968). Both the literature help and the data set were used in this research to define codes and categories by following the above steps. Besides, two field experts were consulted for the suitability of the codes and categories. Opinions were received from experts on naming codes and categories as well as for the distribution of codes into categories. The reliability value calculated with the Kappa formula is .88 .

\section{Study 2}

EFA and CFA analyzes were performed in Study 2. First of all, anti-image, item correlations, determinant coefficients, KMO, and Bartlett test results were evaluated to determine whether the data set was suitable or not. EFA was conducted using the principal component analysis with varimax rotation to assess the construct validity of the scale. To assess the validity of the items to be used in the scale, the item-total correlations were tested, the variance of the common factor and the load value of the item-factor were examined. Besides, inter-factor correlations were determined and reliability analyzes were performed. Cronbach Alpha internal consistency, Guttman, and Spearman-Brown splithalf reliability coefficients were investigated for the sub-dimensions of the scale and total reliability. Then, the second-order CFA was performed to check the model fit of the scale, and the fit indices were reported. EFA is performed via SPSS 24.0 while the CFA is applied using LISREL 8.80 (Jöreskog \& Sörbom, 2007).

\section{FINDINGS}

The findings of both phases of the study are presented under separate headings.

\section{Study 1}

This section contains qualitative findings. Primary school teachers were asked why primary school teaching is a difficult profession and what are the fundamental skills that a primary school teacher must- 
have. The codes obtained were combined under five categories: "Being a teacher in a village school", "Problems originating from management, colleagues, and parents", "Student self-care / close attention", "Pedagogical skills" and "Personal and professional development". Table 1 contains categories and codes.

Table 1 indicates that the first category attained as a result of the study is about being a teacher in a village school. Participants cited working in a village school with multi-grade (united) classrooms and being the principal-authorized teacher or the only teacher among the difficult situations that primary school teachers might encounter. When we look at the category of working in a village school, the infrastructural deficiencies, staying in the lodgments, firing heating stoves, adaptation to the environment and social-cultural activities and transportation problems are among the most emphasized issues. In addition to all this, the shortage of staff allocated to cleaning the school and the inadequacy of health services are causing problems for teachers. While the participants who had their vehicles stressed that they had faced fewer of the issues listed above, it was found that most of the newly appointed teachers did not have a vehicle at that time. To illustrate this point, we can take a closer look at the statement of $\mathrm{T} 4$ as follows:

\begin{abstract}
"Being a teacher in a village school in united classes is a challenge in itself. Your job becomes more difficult, especially if you are the only teacher. You have to be both an administrator and a teacher. Living all alone in the lodgment, firing the stoves of the school and the lodgment, finding resources for the needs of the school are challenging. (Line, 45-47)." Also T37 states that "the nearest health center was $30 \mathrm{~km}$ away and I did not have a car. If you feel sick and have a fever at night, you will either find someone with a car from the village or wait for the morning. You have no other choice (Line, 27-28)."
\end{abstract}

Table 1.

Challenges and Fundamental Skills

\begin{tabular}{|c|c|}
\hline Category & Code \\
\hline $\begin{array}{l}\text { Being a teacher in a village } \\
\text { school }\end{array}$ & $\begin{array}{l}\text { Being a teacher in a village school in multi-grade classrooms } \\
\text { Being a principal authorized teacher } \\
\text { Being the only teacher at school } \\
\text { Insufficient physical facilities of the school } \\
\text { Living in lodgment } \\
\text { The infrastructural deficiencies of the lodgment } \\
\text { Transportation problems } \\
\text { Firing heating stove } \\
\text { Keeping school and classroom clean } \\
\text { Providing resources for the needs of the school } \\
\text { Adaptation to the environment } \\
\text { Lack of healthcare services } \\
\text { Insufficiency of social and cultural activities }\end{array}$ \\
\hline $\begin{array}{l}\text { Management, colleague, and } \\
\text { parent-related problems }\end{array}$ & $\begin{array}{l}\text { Communication with local government } \\
\text { Communication with the school administration } \\
\text { Communication with the Provincial / District Directorate of National } \\
\text { Education } \\
\text { Communication with parents } \\
\text { Parents' lack of interest } \\
\text { Possible problems during parent visits } \\
\text { Peer collaboration and communication }\end{array}$ \\
\hline $\begin{array}{l}\text { Student self-care / close } \\
\text { attention }\end{array}$ & $\begin{array}{l}\text { To give students the habit of cleaning and hygiene } \\
\text { Holding student's hand } \\
\text { Tying student's hair / wiping his or her nose when necessary } \\
\text { Helping the student put on his / her clothes } \\
\text { Bandaging light wounds of the student } \\
\text { Comforting and supporting the student } \\
\text { Playing games with students when necessary }\end{array}$ \\
\hline
\end{tabular}


Table 1. (Continued)

Challenges and Fundamental Skills

\begin{tabular}{ll}
\hline Category & Code \\
\hline Pedagogical skills & Teaching fundamental language skills \\
& Teaching basic language skills to students who do not speak Turkish \\
& Teaching basic math skills \\
& Understanding the physiological, psychological, and social needs of students \\
& Organizing teaching activities according to student interests and needs \\
& To use educational technologies effectively \\
& Using the schedule of reinforcement and giving feedback \\
& To motivate to learn \\
& To use cooperative learning environments actively \\
\hline Personal and Professional & Inadequate income \\
Development & Participating in in-service training \\
& Studying postgraduate degree \\
& Having not enough time and opportunity \\
& Losing your professional ideals \\
\hline
\end{tabular}

Another concern applies to potential problems relating to school administration, colleagues and parents. It was determined that some of the participants had problems, especially with the village representative. The source of the problem is stated as not being able to get support from the local representative for providing resources to meet the needs of the school and his tendency to intervene in the functioning of the school like a senior administrator. T2's statement of "I can never forget the local representative of the village. He thought he was the Director of National Education. So that he even tried to interfere with me regarding whether or not to take students to a physical education class (Line, 35-36)." can be given as an example. Besides, the participants reported that they had some issues with the school administration or the Provincial/Directorate of National Education, stressing that village teachers, in particular, are facing the relevant state departments in the process of fulfilling the physical needs of the school. While certain participants said that they had severe communication problems with their parents who do not speak Turkish, almost all of the participants said that they regarded indifference from their parents as a major issue. Participants stressed that close contact with parents is more important in primary school compared to other grades and claimed that primary school teachers would face many problems in the field of education unless there is the assistance of parents. Also, the participants reported that their communication and collaboration with their colleagues equipped them with great advantages in addressing the difficulties they had experienced. Some of the participants stressed that certain colleagues of them whom they found intolerant harmed the harmony and productivity of the school environment.

Another point emphasized by the participants as the difficulty of the primary school teaching profession is to support students' self-care and to show close attention. It can be thought that it makes complete sense for the participants to pay attention to these challenges, given the developmental characteristics of primary school children. Certain participants stated that students should gain a habit of cleaning and this would take a long time for the teacher to achieve it. Another issue is that the teacher holds the hand of the students and enables them to write when needed or the students want to hold their teacher's hand. T43:

"It took time for me to get used to. A high school student does not hold his or her teacher's hand and does not make such an attempt. But the primary school student is not like that, the students want to touch or even hug. The children do not pay much attention to hand hygiene. However, they wanted to be close to me and hold my hand outside the class. Actually, they are trying to show their love. I know that many of my friends who are obsessed with cleaning and being hygienic have significant problems in this regard. But I chose to adopt my students the cleaning habit (Line, 83-85)."

This statement expresses the need to give students a habit of cleaning and that primary school students are willing to make physical contact with their teachers because of their developmental characteristics. Also, the participants stated that when necessary, they tie up their students' hair, clean their faces 
especially in primary school, help them wear coats or shoes, and perform basic first aid interventions in minor injuries. T80 states that:

\begin{abstract}
"A primary school teacher is like a parent. If needed, the teacher wipes the student's nose, puts on his or her coat and shoes, takes his or her hand when he or she cries, grieves and then comforts him or her, holds hands, and plays games. It is really difficult for someone who cannot do these to be a primary teacher or put in this way, a happy primary school teacher (Line, 19-22)."
\end{abstract}

As can be understood from the statement, primary school students may be inadequate in performing their self-care and personal hygiene. Primary school teachers have to be closer to the students and more interested in them compared to their colleagues working in higher grades. Indeed, T80 states that primary school teachers who cannot demonstrate these skills, cannot be happy in their professional life and also indicates that these behaviors should be present in a primary school teacher.

Another point made by the participants about the characteristics that the primary school teacher should have is pedagogical skills. Undoubtedly, primary school teachers' most efforts are teaching primary reading and writing as well as basic mathematical skills. The teaching of these skills, which constitute the backbone of a student's academic life, occurs in the first years of primary school. In this way, one of the challenges that primary school teachers encounter is the acquisition of basic language skills by students who do not have adequate knowledge of Turkish. T54 states the following sentences:

\begin{abstract}
"Working in the village school has many difficulties. Some of my students who started the first grade in the place where I was assigned, was not able to speak Turkish. I had Syrian immigrant students. You cannot apply a similar program to a student in this condition. You have to teach those kids the Turkish language first (Line, 74-77)."
\end{abstract}

As can be interpreted from this statement, teaching children who do not speak Turkish with basic language skills is one of the challenges that primary school teachers must address. Participants concluded that primary school teachers should understand the physiological, psychological, and social needs of their students while taking into consideration the developmental characteristics of them, and also stressed that teachers should assess both these needs and the desires of their students while planning teaching activities. About this matter, expressions of T22 and T59 are as follows:

T22: "Can a high school teacher look into the eyes of a student and tell if he or she has a problem? It's really tough, I suppose, because there may not be a chance to get to know the student well enough. But we spend 4-5 years with the same students. Naturally, we know our students and can understand their moods. Of course, this is a distinctive skill for a primary school teacher (Line, 9497).”

T59: "A primary school teacher should be able to understand from the actions of a student if there is something wrong that day, or whether s/he is hungry, bored, uneasy, in short, all possible feelings. Because the primary school student does not hide feelings. Primary school student is like clear glass. When you look, you can see what's inside. Of course, this takes a certain effort and time (Line, 45 49)."

The above statements provide an insight about the problems that a primary school teacher should pay close attention to, but also give an idea as to why primary school teaching is a challenging profession. T75 says the following:

\footnotetext{
"When we start teaching, it is not easy to reach technological tools. Currently, all central schools have smart boards and internet infrastructure. But the important thing is being able to use it. Technology both enriches learning environments and activates the sensory characteristics of students. This is much more meaningful and interesting for primary school students. Therefore, a primary school teacher should be able to use technology effectively (Line, 117-122)."
}

Hence, we can understand that the role of the digital instructor is considered very important for a primary 
school teacher. The benefits of using technology in primary school are shown by both the development characteristics of students and the multiple learning environments provided by technology. Concerning pedagogical skills, the participants stressed that they would have trouble using the schedule of reinforcement, and may have indecision, especially when selecting a reinforcer. Participants have pointed out the fact that it takes practice to address this issue and the developmental characteristics of students need to be taken into account, especially in providing feedback and using reinforcers. Another point emphasized by the participants is related to the efforts to increase students' motivation to learn. When we look at the statement of T9 as:

"The group of students in front of you is between the ages of 6 and 10. To motivate these students, you must follow a very different way than the one you would follow for a high school student. "I will ask this in the exam, you will need to answer it in the central exam." You can't say something like that. So that, you need to transform learning activities into engaging and fun activities (Line, 8487)."

We see that it is more difficult to motivate learning in primary school than higher grades. And this participant also suggests that a teacher should find ways to attract attention and make it fun to increase the motivation of students. Some of the participants stated that they had difficulties in creating cooperative learning environments. T24 mentions the following;

"Teachers, especially those working in multigrade (united) classrooms should be able to ensure that higher grade students work among themselves while he or she takes care of first-grade students. Guiding students to individual studying constantly may cause them to get bored. You will also lack the power of social learning. However, it is very difficult to ensure that cooperative learning environments in primary school are used actively and efficiently. In this regard, the teacher must be equipped with relevant skills and lead the role of a guide (Line, 176-181)."

The statement can be given as an example of this situation. Students' age and developmental characteristics can hinder the effective utilization of cooperative learning environments. The absence of a leader student in the groups causes the collaborative not to work effectively.

The last point stressed by primary school teachers, especially concerning the challenging aspects of teaching in village schools, is the personal and professional development problems they face. Participants claimed that some of the special training they would want to attend, which is not included the in-service training provided by the Ministry of National Education, is financially challenging. Besides, the participants stated that adequate in-service training opportunities were not provided. Also, the participants mentioned the difficulties of getting a postgraduate education. T41 says that:

"In this regard, any branch teacher is significantly more advantageous than we are. In this way, they can bundle lesson hours and set aside one day per week for graduate education. A primary school teacher working in the village does not have such an advantage. We are at school for five days. But, we cannot attend our graduate courses even though we register for them (Line, 99-102)."

This statement highlights that it may not be possible for the teachers serving in a village to allocate a weekday for their graduate education. Also, the participants pointed out that universities do not offer weekend classes which is a major setback. Last but not least, the participants stressed that they did not have adequate time and opportunities for both personal and professional training, and the demanding circumstances led them to compromise their ideals and dreams after a while.

\section{Study 2}

The findings of study 1 , the findings of validity and reliability studies of the SEBS created for primary school teachers after consulting expert opinions and literature guidance, are discussed in this section.

First of all, 30 items of scale in the item pool were applied to 501 PST candidates and EFA was 
performed. As a consequence of the study, 11 items were omitted from the analysis because they did not have the criteria required for the analysis to proceed. Items were removed from the scale form one by one and necessary analyzes were repeated after each removal. Anti-image correlations were first checked to check the appropriateness of the 19-item scale form for analysis. Of related values, we see that they range between .76 and .94 . Then, the matrix of correlation showing the reciprocal relations of the items in the scale was examined. The correlation matrix showed that each item in the scale form correlates with at least three items with a correlation value of .38 and above. Also, since there is no correlation at .90 and above between any two items in the matrix provides evidence that there is no multicollinearity problem. To decide if there is a multicollinearity problem, the determinant coefficients of the related value were also analyzed and it was found to be .01. These findings reveal that each scale item is appropriate for factor analysis. However, to determine whether the sample size is suitable for factor analysis, the KMO value was examined, and the relevant value was found as .916. To test whether the multivariate normal distribution assumption was achieved, Bartlett's test of sphericity results was examined $\left(X_{(171)}^{2}=4629.705, p=.000\right)$. Before determining the number of factors, the scree plot was also examined and it was determined that the structure consisted of three factors. Table 2 shows the factor structure of the scale and the explained variance rates of the factors as well as the total variance ratio.

Table 2.

Eigenvalues of Factors and Explained Variance Ratios

\begin{tabular}{lccc}
\hline Factor & Eigenvalues & $\%$ of Variance & Cumulative \% \\
\hline 1.Pedagogical skills & 7.290 & 31.357 & 31.357 \\
2. Close attention to the student & 2.272 & 15.269 & 46.626 \\
3.Working in a village school & 1.408 & 11.109 & 57.735 \\
\hline
\end{tabular}

Table 2 indicates that a three-factor structure with the lowest eigenvalue of 1, including at least four items, had approximately 11 percent variance on its own and explained about 58 percent of the total variance. The rotated principal component analysis results are shown in Table 3.

Table 3.

Principal Component Analysis Results

\begin{tabular}{|c|c|c|c|c|c|}
\hline \multirow{2}{*}{ Factor } & \multirow{2}{*}{ Item } & \multirow{2}{*}{ Extraction } & \multicolumn{3}{|c|}{ Component } \\
\hline & & & Factor 1 & Factor 2 & Factor 3 \\
\hline \multirow{11}{*}{ Pedagogical skills } & 1 & .509 & .678 & & \\
\hline & 2 & .535 & .711 & & \\
\hline & 3 & .518 & .685 & & \\
\hline & 4 & .378 & .574 & & \\
\hline & 5 & .670 & .797 & & \\
\hline & 6 & .608 & .754 & & \\
\hline & 7 & .494 & .595 & & \\
\hline & 8 & .474 & .602 & & \\
\hline & 9 & .694 & .816 & & \\
\hline & 10 & .752 & .855 & & \\
\hline & 11 & .700 & .820 & & \\
\hline \multirow{4}{*}{ Close attention to the student } & 12 & .572 & & .719 & \\
\hline & 13 & .660 & & .779 & \\
\hline & 14 & .758 & & .853 & \\
\hline & 15 & .689 & & .806 & \\
\hline \multirow{4}{*}{ Working in a village school } & 16 & .491 & & & .678 \\
\hline & 17 & .599 & & & .762 \\
\hline & 18 & .463 & & & .643 \\
\hline & 19 & .406 & & & .562 \\
\hline
\end{tabular}

Table 3 shows the common factor variance for each scale item varies between .378 and .758 . The pedagogical skills factor consists of items between 1-11 and the factor loading values of the items in this factor range between .574 and .855 . It is found that the showing close attention to students' factor 
includes items between 12-15 and the factor load values of the items in this factor ranges between .719 and .853 . Working in the village, which is the last factor of the scale, includes items between 16-19, and the factor load values of the items in the relevant factor range between .562 and .762 . To determine the relationship between the factors of the scale, Pearson Product-Moment Correlation analysis was performed and the findings are presented in Table 4.

Table 4.

Factor Intercorrelations

\begin{tabular}{lll}
\hline & \multicolumn{1}{c}{1} & 2 \\
\hline 1.Factor 1 & & \\
2.Factor 2 & $.381^{* *}$ & \\
3.Factor 3 & $.428^{* *}$ & $.370^{* *}$ \\
\hline$* * \mathrm{p}<.01$ & &
\end{tabular}

Table 4 shows the correlations between the sub-factors of the scale. It is understood that there's a positive, moderate, and significant relationship between sub-dimensions ( $\mathrm{p}<.01)$. At the same time, the values in the table show that there is no multicollinearity problem between factors. Within the scope of EFA, reliability analysis was performed for the sub-dimensions and overall scale, and the findings are presented in Table 5.

Table 5.

Reliability Analysis Findings

\begin{tabular}{lccc}
\hline & Cronbach's Alpha & Guttman & Spearman-Brown \\
\hline Factor 1 & .920 & .880 & .884 \\
Factor 2 & .834 & .796 & .799 \\
Factor 3 & .753 & .721 & .722 \\
Total & .906 & .809 & .811 \\
\hline
\end{tabular}

Table 5 shows the Cronbach Alpha coefficient measuring internal consistency, Guttman and SpearmanBrown split-halves reliability coefficients regarding the sub-dimensions and overall scale. It strikes attention that relevant values of sub-factors are at .70 and above. Cronbach Alpha internal consistency coefficient for the entire scale calculated as .906 while the Guttman coefficient is .809 and lastly the Spearman-Brown coefficient is .811 . These values provide clues about the reliability of the scale.

Data was collected from PSTs $(n=262)$ to check the goodness of fit of the structure obtained as a result of EFA, and then, a second-order CFA was performed. As a result of the analysis, we see that the chisquare goodness of fit value was significant $\left(\mathrm{X}_{(149)}{ }=307.21, \mathrm{p}=.000\right)$. In this case, other fit indices should be examined. Model fit indices are listed in Table 6.

Table 6.

Findings Regarding Second Level CFA

\begin{tabular}{lcccc}
\hline \multirow{2}{*}{ Indexes } & \multicolumn{2}{c}{ Criteria* $^{*}$} & \multirow{2}{*}{ Finding } & \multirow{2}{*}{ Result } \\
\cline { 2 - 4 } & Perfect Fit & Acceptable Fit & & \\
\hline $\mathrm{X}^{2} / \mathrm{df}$ & $0-2.5$ & $2.5-3$ & 2.06 & Perfect \\
RMSEA & $\leq .05$ & $\leq .08$ & .064 & Acceptable \\
RMR & $\leq .05$ & $\leq .08$ & .079 & Acceptable \\
SRMR & $\leq .05$ & $\leq .08$ & .059 & Acceptable \\
NFI & $\geq .95$ & $\geq .90$ & .95 & Perfect \\
NNFI & $\geq .95$ & $\geq .90$ & .97 & Perfect \\
CFI & $\geq .95$ & $\geq .90$ & .97 & Perfect \\
IFI & $\geq .95$ & $\geq .90$ & .97 & Perfect \\
RFI & $\geq .95$ & $\geq .90$ & .94 & Acceptable \\
GFI & $\geq .90$ & $\geq .85$ & .89 & Acceptable \\
AGFI & $\geq .90$ & $\geq .85$ & .86 & Acceptable \\
\hline${ }^{*}$ (Schumacker \& Lomax, 2004) & &
\end{tabular}


When the fit index values in Table 6 are examined, $X^{2} / d f$, NFI, NNFI, CFI, and IFI values show a perfect fit while the RMSEA, RMR, SRMR, RFI, GFI, and AGFI values are seen to have an acceptable fit. The structure of the model (Item-Total Correlations) consisting of 3 factors and 19 items is shown in Figure 4.

Figure 4.

Model Related Structure (Item-Total Correlations)

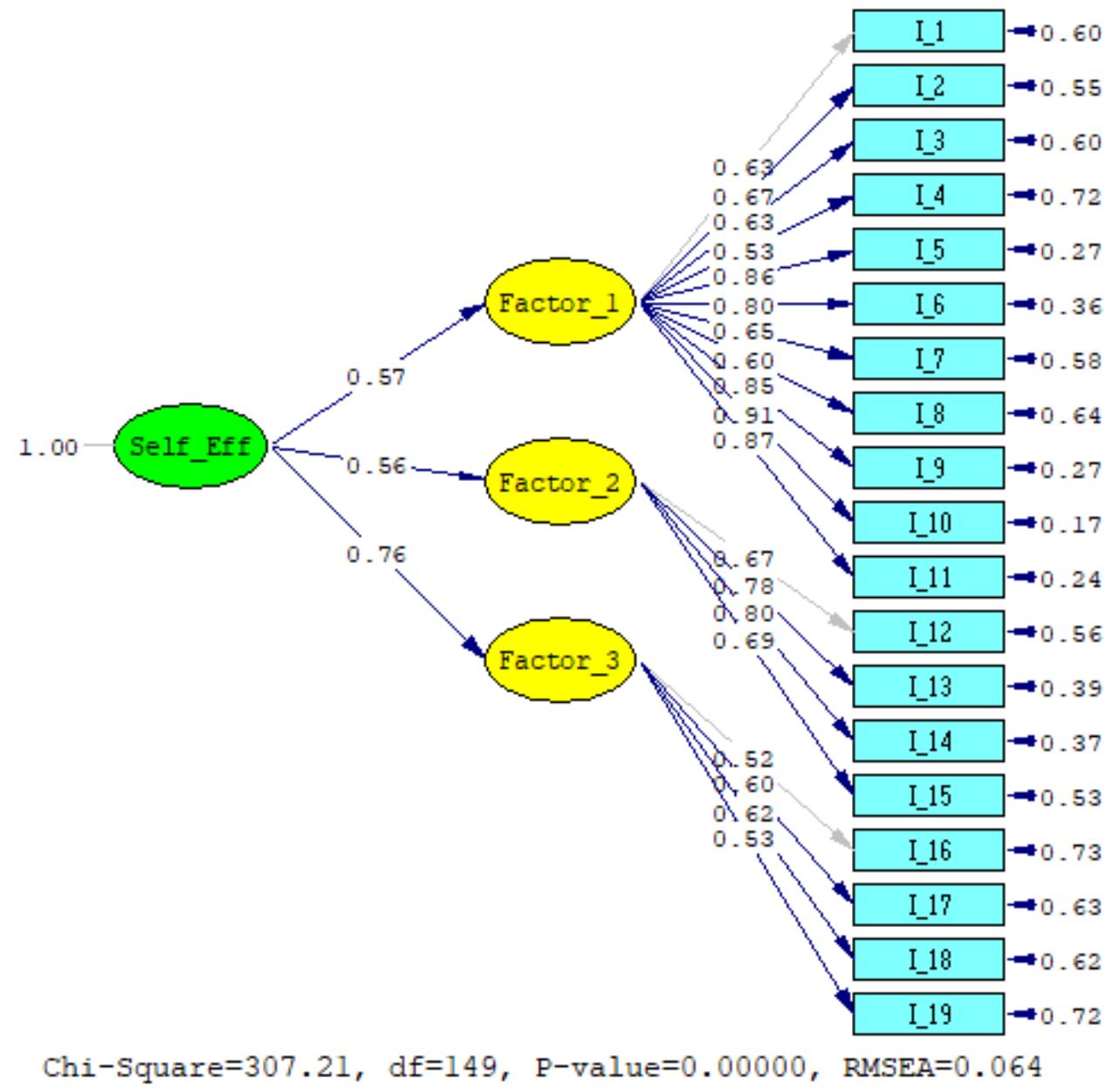

When Figure 4 is examined, we see that the item-total correlation values range between .52 and .91 . These coefficients indicate the correlation between each variable and the latent variable. The higher the correlation coefficient, the higher the corresponding variable explains the latent variable. In this context, one can argue that the scale items show a high level of correlation and show the goodness of fit for distinguishing the targeted feature. In Figure 5 below, there is a diagram showing the $t$ values of the items. 
Figure 5.

Model Structure ( $t$ Values)

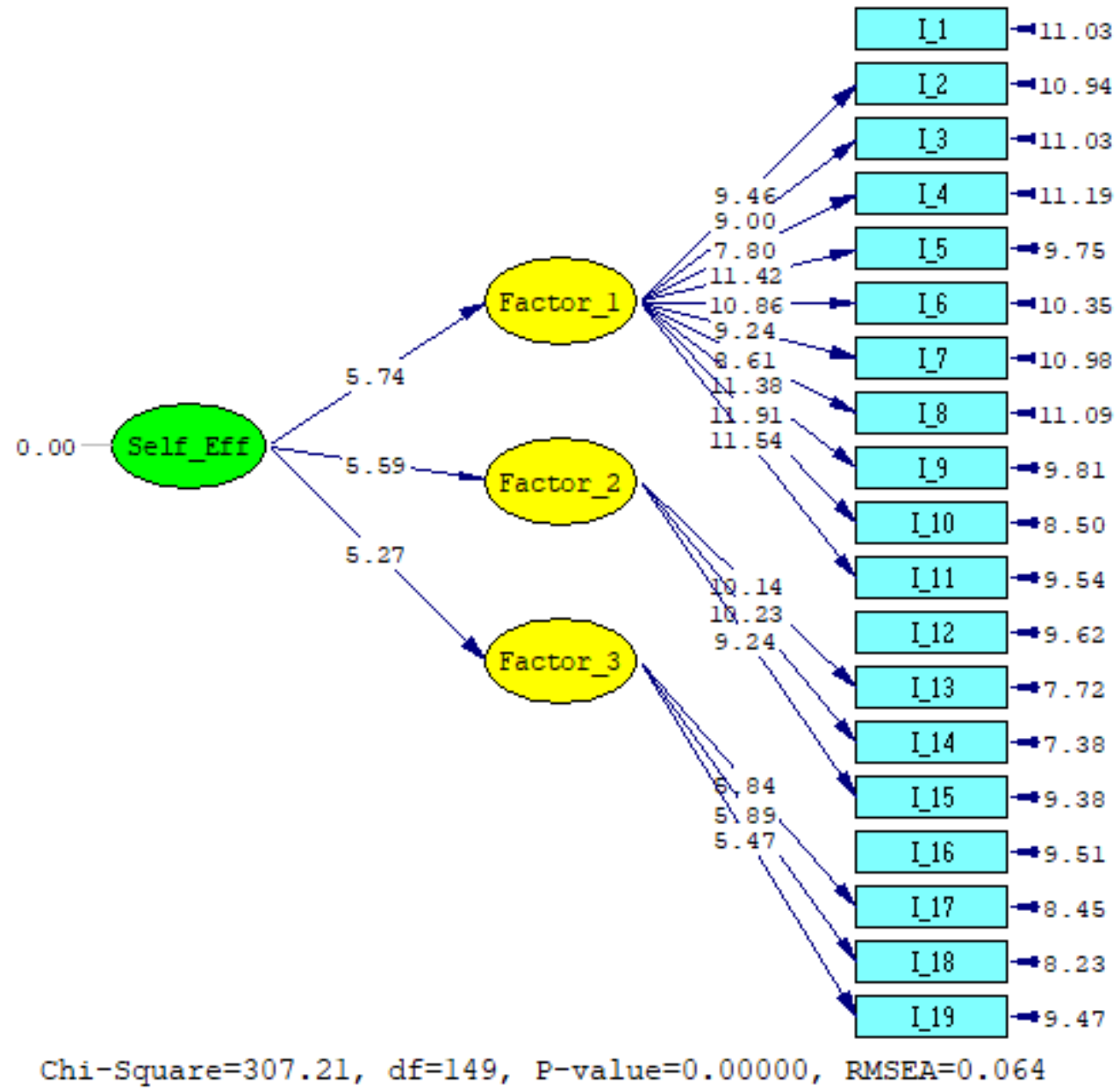

When the diagram in Figure 5 is examined, we see that $t$ values are significant for all variables. This provides evidence that the relevant items are not intended to measure the same property. In this case, it can be claimed that the items in the scale are meant to compare different features and that the model fit is achieved.

\section{DISCUSSION, CONCLUSION, AND SUGGESTIONS}

The study was conducted according to the exploratory sequential design, one of the fundamental designs of mixed research, in which qualitative method and quantitative method were used together. This study aims to develop a SEBS to determine the self-efficacy beliefs of PSTs and PST candidates based on the opinions of PSTs.

In the qualitative method part of the study, per the views of primary school teachers, the quantitative method part followed a phase that ended with the development of a scale. In the qualitative method part of the study, the data obtained from primary school teachers were analyzed by descriptive analysis and content analysis method. Primary school teachers were asked why primary school teaching is a difficult profession and what are the fundamental skills that a primary school teacher must-have. Based on the data obtained, five the category which is (i) being a teacher in a village school, (ii) problems originating from management, colleagues, and parents, (iii) student self-care / close attention, (iv) pedagogical skills, and (v) personal and professional development" were developed. 
In the quantitative method of the study, first, exploratory factor analysis was performed. The draft form was finalized by building up a pool of items generated based on the results of Study 1 and with the help of the literature, following expert opinions. The draft form was applied to 501 PST candidates for EFA. The appropriateness of the data set for analysis was examined. First, the Anti-image correlation matrix was checked and it was seen that the values range between .76 and. 94. Durmuş et al. (2013) state that the values in this matrix should be greater than 0.50 . Then, item correlations were examined, and it was observed that each item correlates with at least three items ranging between .38 and.87. Field (2013) points out the matter that in a correlation matrix, each item should exhibit a significant relationship with at least two different items at .30 and above, and they should not show a relationship of .90 or more. Determinant coefficients were also examined to determine whether the multicollinearity problem exists. Field reports that if this value is above $10^{-5}$, there is no multicollinearity problem. KMO test has been applied to determine whether the data set is suitable for sampling and the value is calculated as .916 . Field states that KMO value should be greater than 0.5 while Pallant (2001) states that it should be greater than 0.6. In this case, it can be stated that the sample is sufficient for analysis.

It is stated that items with low common factor variance in the EFA may be excluded from the analysis and that the total variance value explained can be increased in this way (Kalayc1, 2009). The items that have common factor variance below .30 were excluded from the form within the scope of the study. We observe that the factor load values of the items in the scale vary between .57 and.86. Consensus on item factor load value is favoring the view that suggesting load value should be .30 and above; however, load factors of .50 and above are well accepted (Kalayc1, 2009). In this context, it can be stated that the factor loading values of the items in the scale are quite good. When examining the distribution of items by factors and the values that items take under the factors, it is stated that the difference between the two load values should be at least .10 (Büyüköztürk, 2007). Items that violate this assumption are called overlapping items. Overlapping items were omitted within the scope of this study. As a result of these processes, a three-factor structure that explains about $58 \%$ of the common variance was obtained. At least $52 \%$ of the variance rate explained by Henson and Roberts (2006) measurement tool while Kline (1994) emphasizes that this ratio should be $40 \%$. Given this situation, it can be said that the variance explained is sufficient. When correlation values between factors are examined, it is possible to claim that there is a positive, moderate, and significant relationship between factors. On top of that, the results of the reliability analysis of the factors and the entire scale indicate that the scale will provide reliable measurements (Durmuş et al., 2013; Fornell \& Larcker, 1981).

Data were collected from 262 PSTs and a CFA was performed to check the goodness of the fit of the structure consisting of three factors. As a result of the analysis, $X^{2} / \mathrm{df}$, NFI, NNFI, CFI, and IFI, values showed a perfect fit, while the RMSEA, RMR, SRMR, RFI, GFI, and AGFI values were found to have an acceptable level of compliance (Büyüköztürk, 2007; Kline, 2005; Schumacker \& Lomax, 2004). When the structure model showing the item-total correlations is examined, we see that the relevant values range between .52 and .91 . In the literature, it is stated that for distinguishing a feature, these values should be at least .30 or more (Büyüköztürk, 2007). It can be said, thus, that the item-total correlation values of the items in the scale are adequate. The structure model displaying $t$ values offered evidence that the related items are not meant to measure the same features. In this case, it can be claimed that the items in the scale are meant to compare different features and that the model fit is achieved.

The scale developed by Tschannen-Moran and Woolfolk Hoy (2001), which is often used in instructor self-efficacy studies in the related literature, also has three factors (ensuring student participation, application of teaching strategies, self-efficacy for classroom management). Bandura (2006) has suggested a scale consisting of six dimensions which are (i) ability to influence decision-making, (ii) educational competence, (iii) disciplinary competence, (iv) competence to receive parent support, (v) competence to receive environmental support, (vi) competence to create a positive school climate to measure teacher self-efficacy. As a result of this scale, the reliability and validity tests were carried out for relevant researchers to determine the self-efficacy of primary school teachers and primary school teacher candidates. Although SEB studies about primary school teachers and teacher candidates are conducted in Turkey, considering that this scale was developed in line with the opinions of the primary 
school teachers serving in Turkey, this scale is thought to be beneficial for relevant researchers. Moreover, we see that this scale is different from the related literature in terms of its items and factors. For example, we can argue that factors of (i) pedagogical skills (ii) close attention to students (iii) working in a village school and their items measure areas different from other SEBSs. That's being said; when we mention nearly 28 percent of teachers in the Turkish education system are primary school teachers, the importance of the scale to the literature cannot be dismissed. Items on the scale of primary school teachers working in village schools demonstrate the value of the scale in assessing the selfefficacy of primary school teachers. Researchers who want to gain an overview of the relevant literature can also look at the bibliometric analysis results. As a result, the factor structure, reliability, and validity of the new measure was examined, as well as the appropriateness of the new scale for both primary school teacher and teacher candidate populations. Also, it can be seen as a limitation of the study that the researchers chose the participants according to the participants of the scale.

\section{Ethical Procedures}

This research was found ethically appropriate with the decision numbered 05-02 at the meeting held by Atatürk University Ethics Committee on 2 March 2020.

\section{REFERENCES}

Akçöltekin, A. (2019). The development of the teachers' self-efficacy scale regarding scientific researches. Kastamonu Education Journal, 27(6), 2713-2727. https://doi.org/10.24106/kefdergi.3707

Akkoyunlu, B., Orhan, F., \& Umay, A. (2005). A study on developing teacher self efficacy scale for computer teachers. Hacettepe University Journal of Education, 29, 1-8.

Aypay, A. (2010). The adaptation study of general self-efficacy (GSE) scale to Turkish. Inonu University Journal of the Faculty of Education, 11(2), 113-131.

Bandura, A. (1977). Self-efficacy: Toward a unifying theory of behavioral change. Psychological Review, 84(2), 191-215. https://doi.org/10.1037/0033-295X.84.2.191

Bandura, A. (1997). Self-efficacy: The exercise of control. Freeman.

Bandura, A. (2006). Guide for constructing self-efficacy scales. In F. Pajares \& T. Urdan (Eds.), Adolescence and education, Vol. 5: Self-efficacy and adolescence (pp. 307-337). Information Age Publishing.

Berg, D. A., \& Smith, L. F. (2016). Preservice teacher self-efficacy beliefs: An opportunity to generate "good research" in the Asia-Pacific region. In Asia-Pacific Perspectives on Teacher Self-efficacy (pp. 1-17). Brill Sense.

Betoret, F. D. (2006). Stressors, self-efficacy, coping resources, and burnout among secondary school teachers in Spain. Educational Psychology, 26(4), 519-539. https://doi.org/10.1080/01443410500342492

Büyüköztürk, Ş. (2007). Sosyal bilimler için veri analizi el kitabı [The guidebook of data analysis for social sciences]. Pegem.

Cantürk-Günhan, B., \& Başer, N. (2007). The development of self-efficacy scale toward geometry. Hacettepe University Journal of Education, 33, 68-76.

Çapa, Y., Çakıroğlu, J., \& Sarıkaya, H. (2005). The development and validation of a Turkish version of the teachers' sense of efficacy scale. Education and Science, 30(137), 74-81.

Caprara, G. V., Barbaranelli, C., Steca, P., \& Malone, P. S. (2006). Teachers' self-efficacy beliefs as determinants of job satisfaction and students' academic achievement: A study at the school level. Journal of School Psychology, 44(6), 473-490. https://doi.org/10.1016/j.jsp.2006.09.001

Chan, D. W. (2008). Dimensions of teacher self-efficacy among Chinese secondary school teachers in Hong Kong. Educational Psychology, 28(2), 181-194. https://doi.org/10.1080/01443410701491833

Chen, G., Gully, S. M., \& Eden, D. (2001). Validation of a new general self-efficacy scale. Organizational Research Methods, 4(1), 62-83. https://doi.org/10.1177/109442810141004

Chesney, M. A., Neilands, T. B., Chambers, D. B., Taylor, J. M., \& Folkman, S. (2006). A validity and reliability study of the coping self-efficacy scale. British Journal of Health Psychology, 11(3), 421-437. https://doi.org/10.1348/135910705X53155

Creswell, J. W. (2014). A concise introduction to mixed methods research. Sage. 
Dellinger, A. B., Bobbett, J. J., Olivier, D. F., \& Ellett, C. D. (2008). Measuring teachers' self-efficacy beliefs: Development and use of the TEBS-Self. Teaching and Teacher Education, 24(3), 751-766. https://doi.org/10.1016/j.tate.2007.02.010

Dey, I. (1993). Qualitative data analysis: A user friendly guide for social scientist. Routledge.

Durmuş, B., Yurtkoru, E. S., \& Çinko, M. (2013). Sosyal bilimlerde SPSS'le veri analizi [Data analysis with SPSS in social sciences] ( $5^{\text {th }}$ ed.). Beta.

Erdem, E., \& Demirel, Ö. (2007). Teacher self efficacy beliefs. Social Behavior and Personality: An International Journal, 35(5), 573-586. https://doi.org/10.2224/sbp.2007.35.5.573

Field, A. (2013). Discovering statistics using IBM SPSS statistics $\left(4^{\text {th }}\right.$ ed.). Sage.

Fornell, C., \& Larcker, D. F. (1981). Evaluating structural equation models with unobservable variables and measurement error. Journal of Marketing Research, 18(1), 39-50. https://doi.org/10.2307/3151312

Gibson, S., \& Dembo, M. H. (1984). Teacher efficacy: A construct validation. Journal of Educational Psychology, 76(4), 569-582. https://doi.org/10.1037/0022-0663.76.4.569

Henry, P., \& Moscovici, S. (1968). Problèmes de l'analyse de contenu [Content analysis issues]. Langages [Languages], 11, 36-60. https://doi.org/10.3406/lgge.1968.2900

Henson, R. K., \& Roberts, J. K. (2006). Use of exploratory factor analysis in published research: Common errors and some comment on improved practice. Educational and Psychological Measurement, 66, 393-416. https://doi.org/10.1177/0013164405282485

Holzberger, D., Philipp, A., \& Kunter, M. (2013). How teachers' self-efficacy is related to instructional quality: A longitudinal analysis. Journal of Educational Psychology, 105(3), 774-786. https://doi.org/10.1037/a0032198

Huang, S., Yin, H., \& Lv, L. (2019). Job characteristics and teacher well-being: the mediation of teacher selfmonitoring and teacher self-efficacy. Educational Psychology, 39(3), 313-331. https://doi.org/10.1080/01443410.2018.1543855

Jöreskog, K., \& Sörbom, D. (2007). LISREL 8 user's guide. Scientific Software.

Kalaycı, Ş. (2009). SPSS uygulamalı çok değişkenli istatistik teknikleri [SPSS applied multivariate statistical techniques] $\left(4^{\text {th }}\right.$ ed.). Asil.

Kim, Y. H. (2011). Prospective early childhood educators' meta-cognitive knowledge and teacher self-efficacy: Exploring domain-specific associations. Educational Psychology, 31(6), 707-721. https://doi.org/10.1080/01443410.2011.599924

Klassen, R. (2002). Writing in early adolescence: A review of the role of self-efficacy beliefs. Educational psychology review, 14(2), 173-203.

Klassen, R. M., \& Chiu, M. M. (2010). Effects on teachers' self-efficacy and job satisfaction: Teacher gender, years of experience, and job stress. Journal of Educational Psychology, 102(3), 741-756. https://doi.org/10.1037/a0019237

Klassen, R. M., \& Tze, V. M. (2014). Teachers' self-efficacy, personality, and teaching effectiveness: A metaanalysis. Educational Research Review, 12, 59-76. https://doi.org/10.1016/j.edurev. 2014.06.001

Kline, P. (1994). An easy guide to factor analysis. Routledge.

Kline, R. B. (2005). Principles and practice of structural equation modeling ( $\left.2^{\text {nd }} \mathrm{ed}.\right)$. Guilford.

Livinti, R., Gunnesch-Luca, G., \& Iliescu, D. (2021). Research self-efficacy: A meta-analysis. Educational Psychologist, 1-28. https://doi.org/10.1080/00461520.2021.1886103

Maddux, J. E., Sherer, M., \& Rogers, R.W. (1982). Self-efficacy expectancy and outcome expectancy: Their relationship and their effects on behavioral intentions. Cognitive Therapy and Research, 6(2), $207-211$. https://doi.org/10.1007/BF01183893

Malinen, O. P., Savolainen, H., Engelbrecht, P., Xu, J., Nel, M., Nel, N., \& Tlale, D. (2013). Exploring teacher self-efficacy for inclusive practices in three diverse countries. Teaching and Teacher Education, 33, 34-44. https://doi.org/10.1016/j.tate.2013.02.004

Martin, J. J., Mccaughtry, N., Hodges-Kulinna, P., \& Cothran, D. (2008). The influences of professional development on teachers' self-efficacy toward educational change. Physical Education and Sport Pedagogy, 13(2), 171-190. https://doi.org/10.1080/17408980701345683

Merriam, S. B. (2009). Qualitative research: A guide to design and implementation. Jossey-Bass.

Miles, M. B., \& Huberman, A. M. (1994). Qualitative data analysis: An expanded sourcebook (2 ${ }^{\text {nd }}$ ed.). Sage.

Morris, D. B., Usher, E. L., \& Chen, J. A. (2017). Reconceptualizing the sources of teaching self-efficacy: A critical review of emerging literature. Educational Psychology Review, 29(4), 795-833. https://doi.org/10.1007/s10648-016-9378-y

Öncü, H. (2012). Adaptation of academic self-efficacy scale into Turkish. Journal of Kırşehir Education Faculty, 13(1), 183-206.

Özgen, K., \& Bayram, B. (2019). Developing problem posing self-efficacy scale. Elementary Education Online, 18(2), 663-680. https://doi.org/10.17051/ilkonline.2019.562029 
Özgen, K., \& Bindak, R. (2008). The development of self-efficacy scale for mathematics literacy. Kastamonu Education Journal, 16(2), 517-528.

Pajares, F. (2003). Self-efficacy beliefs, motivation, and achievement in writing: A review of the literature. Reading \&Writing Quarterly, 19(2), 139-158. https://doi.org/10.1080/10573560308222

Pallant, J. (2001). SPSS survival manual. Open University Press.

Pendergast, D., Garvis, S., \& Keogh, J. (2011). Pre-service student-teacher self-efficacy beliefs: An insight into the making of teachers. Australian Journal of Teacher Education, 36(12), 46-57. http://dx.doi.org/10.14221/ajte.2011v36n12.6

Ross, J. A., Cousins, J. B., \& Gadalla, T. (1996). Within-teacher predictors of teacher efficacy. Teaching and Teacher Education, 12(4), 385-400. https://doi.org/10.1016/0742-051X(95)00046-M

Schumacker, R. E., \& Lomax, R. G. (2004). A beginner's guide to structural equation modeling. Psychology Press.

Schunk, D. H. (1985). Participation in goal setting: Effects on self-efficacy and skills of learning-disabled children. The Journal of Special Education, 19(3), 307-317. https://doi.org/10.1177/002246698501900307

Skaalvik, E. M., \& Skaalvik, S. (2007). Dimensions of teacher self-efficacy and relations with strain factors, perceived collective teacher efficacy, and teacher burnout. Journal of Educational Psychology, 99(3), 611625. https://doi.org/10.1037/0022-0663.99.3.611

Skaalvik, E. M., \& Skaalvik, S. (2010). Teacher self-efficacy and teacher burnout: A study of relations. Teaching and Teacher Education, 26(4), 1059-1069. https://doi.org/10.1016/j.tate.2009.11.001

Tavşanc1l, E. (2014). Measuring attitudes and data analysis with SPSS (5 $5^{\text {th }}$ ed.). Nobel.

Tschannen-Moran, M., \& Woolfolk Hoy, A. (2001). Teacher efficacy: Capturing an elusive construct. Teaching and Teacher Education, 17(7), 783-805. https://doi.org/10.1016/S0742-051X(01)00036-1

Tuchman, E., \& Isaacs, J. (2011). The influence of formal and informal formative pre-service experiences on $\begin{array}{llll}\text { teacher } & \text { self-efficacy. } & \text { Educational } & \text { Psychology, }\end{array}$ https://doi.org/10.1080/01443410.2011.560656

Usher, E. L., \& Pajares, F. (2008). Sources of self-efficacy in school: Critical review of the literature and future directions. Review of Educational Research, 78(4), 751-796. https://doi.org/10.3102/0034654308321456

Veneziano, L., \& Hooper, J. (1997). A method for quantifying content validity of health-related questionnaires. American Journal of Health Behavior, 21(1), 67-70.

Yıldırım, A., \& Şimşek, H. (2013). Qualitative research methods in the social sciences ( ${ }^{\text {th }}$ ed.). Seçkin.

Zee, M., \& Koomen, H. M. (2016). Teacher self-efficacy and its effects on classroom processes, student academic adjustment, and teacher well-being: A synthesis of 40 years of research. Review of Educational Research, 86(4), 981-1015. https://doi.org/10.3102/0034654315626801 


\section{APPENDIX}

\section{Teacher SEBS for Primary School Teachers}

Dear participant,

This scale has been developed to determine your SEB levels towards the teaching profession. As there are reverse items in the scale, it is very essential for the reliability of the results that you read all items carefully and mark the option that best suits you. Thank you for your voluntary participation.

\begin{tabular}{|c|c|c|c|c|c|}
\hline ITEMS & 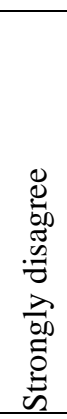 & 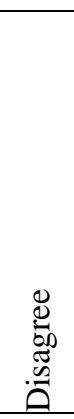 & 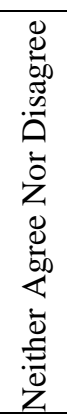 & 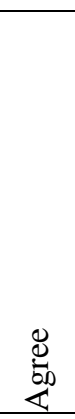 & 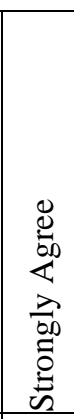 \\
\hline 1. I can deal with any problem that occurs in the class. & (1) & (2) & (3) & (4) & (5) \\
\hline 2. I can organize teaching activities according to the needs of my students. & (1) & $(2)$ & (3) & (4) & (5) \\
\hline 3. I may have difficulty using educational technologies effectively. $* *$ & $(1)$ & $(2)$ & $(3)$ & $(4)$ & $(5)$ \\
\hline 4. I can communicate effectively and work collaboratively with my colleagues. & (1) & (2) & (3) & (4) & (5) \\
\hline 5. One of the most challenging things for me is communicating with parents. ** & (1) & $(2)$ & (3) & (4) & $(5)$ \\
\hline 6. I can carry a researcher teacher identity until the end of my professional life. & (1) & $(2)$ & (3) & (4) & $(5)$ \\
\hline 7. When needed, I can hold my student's hands and help writing. & (1) & $(2)$ & (3) & (4) & (5) \\
\hline 8. The thought of playing games with my students makes me nervous. $* *$ & (1) & $(2)$ & (3) & (4) & $(5)$ \\
\hline 9. I can plan my lessons in line with my students' interests and curiosity. & (1) & $(2)$ & (3) & (4) & $(5)$ \\
\hline 10. I can choose the appropriate method and technique for teaching activities. & $(1)$ & $(2)$ & (3) & $(4)$ & $(5)$ \\
\hline 11. I do not believe that I can make an effective assessment and evaluation. ** & (1) & $(2)$ & (3) & (4) & (5) \\
\hline 12. I can clean my students' hands and face when needed. & (1) & $(2)$ & (3) & (4) & $(5)$ \\
\hline 13. When my students are injured, I can do simple first aid. & (1) & $(2)$ & (3) & (4) & (5) \\
\hline 14. It can be uncomfortable for me to wear my students' coats. $* *$ & (1) & $(2)$ & (3) & (4) & $(5)$ \\
\hline $\begin{array}{l}\text { 15. I think it's natural for my students to grab my hand or hug me outside the } \\
\text { classroom. }\end{array}$ & (1) & (2) & (3) & (4) & (5) \\
\hline $\begin{array}{l}\text { 16. I can work comfortably in a village school with multi-grade (united) } \\
\text { classrooms. }\end{array}$ & (1) & (2) & (3) & (4) & (5) \\
\hline $\begin{array}{l}\text { 17. It makes me worried whether the utilities and transport services in the village } \\
\text { where I will be assigned are inadequate. } * *\end{array}$ & (1) & (2) & (3) & (4) & (5) \\
\hline 18. I can stay in the lodgement of the village school. & (1) & (2) & (3) & (4) & (5) \\
\hline 19. I can fire a stove in school or lodgement without any help from anyone. & (1) & $(2)$ & (3) & (4) & (5) \\
\hline
\end{tabular}




\section{TÜRKÇE GENIŞLETILMIŞ ÖZET}

Öğretmenlik, insanlık tarihinin en eski mesleklerinden biri olarak kabul edilebilmektedir. İnsanlık var oldukça da öğretmenlik mesleği devam edecektir. Öğretmenler okul öncesi dönemden başlayarak lisansüstü döneme kadar görev alabilmektedirler. Genel olarak öğretmenlerin görev ve sorumluluklar1 benzer olsa da öğretimin her kademesinde öğretmenlik mesleği kendine özgü bazı değişimler gösterebilmektedir. Örneğin temel eğitimde görevli olan okul öncesi ve sınıf öğretmenlerinin öğrenci ile iletişimleri ve öğrenciye yaklaşımları daha üst düzey kademelere göre farklı olabilmektedir. Hangi öğretim kademesinde olursa olsun öğretmenliğin kendine özgü bazı zorlukları bulunmaktadır. Bununla beraber öğretmenlik mesleğini tercih edecek bireylerde bulunması gereken bazı temel becerilerin varlığı da söz konusudur. $\mathrm{Bu}$ bağlamda değerlendirildiğinde ilkokuma ve yazma ile temel matematik becerilerinin kazandırıldığı ve örgün eğitimin temelinin atıldığı ilkokullarda, sınıf öğretmenliği yapmanın zorluklarının ve bir sınıf öğretmeninde bulunması gereken temel becerilerinin belirlenmesi önemli görülmektedir. Ayrıca doğrudan sınıf öğretmenliği mesleğine yönelik bir öz-yeterlik inanç ölçeğinin bulunmaması da çalışmayı daha önemli hale getirmektedir. Nitekim alanyazında yer alan ve öğretmenlere yönelik geliştirilen mesleki öz-yeterlik ölçekleri incelendiğinde sınıf öğretmenliğine özel bazı durumlardan hiç bahsedilmediği anlaşılabilir. Buradan hareketle mevcut araştırmada, sınıf öğretmenliği mesleğinin güç yönlerini ve bir sınıf öğretmeninde bulunması gereken temel becerileri, sınıf öğretmenlerinin görüşleri doğrultusunda açığa çıkarmak; sınıf öğretmeni ve sınıf öğretmeni adaylarının öz-yeterlik inançlarını tespit edebilmek için bir öz-yeterlik inanç ölçeği geliştirilmek amaçlanmıştır.

$\mathrm{Bu}$ çalışmada hem nitel hem de nicel yöntemlerden yararlanılmıştır. İlk olarak sınıf öğretmenlerinden, sınıf öğretmenliğinin neden zor bir meslek olduğu, sınıf öğretmeninde bulunması gereken temel becerilerin neler olduğuyla ilgili nitel veriler toplanmış ve analiz edilmiştir. Çalışmanın ikinci kısmında ölçek geliştirme aşamaları takip edilmiş; nitel bulgulardan hareketle madde havuzu oluşturulmuştur. Alanyazın desteğiyle birlikte madde havuzu zenginleştirilmiştir. Elde edilen taslak ölçek formu, iki ayrı aşamada, sınıf öğretmenlerine ve sınıf öğretmeni adaylarına uygulanarak sınıf öğretmenleri için özyeterlik inanç ölçeğinin geçerlik ve güvenirlik analizleri tamamlanmıştır. Çalışmanın ilk aşaması en az beş yıllık mesleki deneyime sahip 80 sınıf öğretmeni ile birlikte yürütülmüştür. $\mathrm{Bu}$ aşamanın katılımcıları ölçüt örnekleme yöntemine göre seçilmiştir. İkinci aşamanın verileri ise toplamda 763 sınıf öğretmeni ve sınıf öğretmeni adayından toplanmıştır. Hazırlanan taslak ölçek formu öncelikle 501 sınıf öğretmeni adayına uygulanarak açımlayıcı faktör analizi yapılmıştır. Daha sonra mevcut yapıyı doğrulamak için 262 sınıf öğretmeninden veri toplanmış ve doğrulayıcı faktör analizi gerçekleştirilmiştir. Çalışma 1'in verileri, sınıf öğretmenleri ile birlikte gerçekleştirilen görüşmeler sonucunda elde edilmiştir. Veriler yarı-yapılandırılmış görüşme formu kullanılarak toplanmıştır. Çalışma 2'de ölçek geliştirme aşamaları takip edilmiştir. Çalışma 1'den elde edilen bulgular ve alanyazın taraması sonucunda elde edilen madde örneklerinden bir havuz oluşturulmuştur. Katılım düzeyini tespit edebilmek amacıyla beşli Likert tipinde derecelendirme sisteminden yararlanılmıştır.

Çalışma 1'in veri analizinde betimsel analiz ve içerik analizi gerçekleştirilmiştir. Betimsel analiz kısmında verilere ait frekans değerleri sunulmuş; gerekli görülen yerlerde doğrudan alıntılara başvurulmuştur. Transkript edilen verilerden hareketle ilk olarak kodlar belirlenmiş; kodlar uygun kategoriler altında birleştirilmiştir. Kodların ve kategorilerin belirlenmesinde hem alanyazın desteğinden hem de veri setinden yararlanılmıştır. Çalışma 2'de açımlayıcı ve doğrulayıcı faktör analizleri gerçekleştirilmiştir. Öncelikle veri setinin uygun olup olmadığını tespit edebilmek amacıyla anti-image, madde korelasyonları, determinant katsayıları, Kaiser-Meyer-Olkin ve Barlett testi sonuçları değerlendirilmiştir. Yapı geçerliği için Varimax döndürme ile temel bileşenler analizi kullanılarak açımlayıcı faktör analizi yapılmıştır. Madde geçerliklerini tespit etmek için madde toplam korelasyonları incelenmiş, ortak faktör varyansı ve madde faktör yük değerleri kontrol edilmiştir. Bununla birlikte faktörler arası korelasyonlar belirlenmiş ve güvenirlik analizler gerçekleştirilmiştir. Ölçeğin alt boyutları ve toplam güvenirlik için Cronbach Alpha iç tutarlık katsayısı, Guttman ve 
Spearman-Brown testi yarılama güvenirlik katsayıları incelenmiştir. Daha sonra ikinci düzey doğrulayıcı faktör analizi yapılarak ölçeğin model uyumu kontrol edilmiş ve uyum indeksleri raporlaştırılmıştır. Açımlayıcı faktör analizi SPSS 24; doğrulayıcı faktör analizi LISREL 8.80 programları kullanılarak gerçekleştirilmiştir.

Sınıf öğretmenlerine, sınıf öğretmenliğinin neden zor bir meslek olduğu ve bir sınıf öğretmeninde bulunması gereken temel becerilerin neler olduğu sorulmuştur. Elde edilen kodlar "Köy okulunda öğretmen olmak", "Yönetim, meslektaş ve veli kaynaklı problemler", "Öğrenci öz-bakımı/yakın ilgi”, "Pedagojik beceriler" ve "Kişisel ve mesleki gelişim" olmak üzere beş kategori altında birleştirilmiştir. Öncelikle madde havuzunda yer alan 30 ölçek maddesi 501 katılımcıya uygulanmış ve açımlayıcı faktör analizi yapılmıştır. Yapılan analiz sonucunda 11 ölçek maddesi, analizlerin devamı için gerekli şartları sağlamadığından analizden çıkarılmıştır. Maddeler ölçek formundan birer birer çıkarılmış; her çıkarım işleminden sonra analizler tekrarlanmıştır. Analiz sonucunda özdeğeri en düşük 1 olan, en az dört madde içeren, tek başına yaklaşık olarak en \%11 varyansa sahip, toplam varyansın yaklaşık \%58'ini açıklayan ve üç faktörden meydana gelen bir yapı ortaya konmuştur. Ölçek maddelerine ait ortak faktör varyansının .378 ile .758 arasında değer aldığı tespit edilmiştir. Pedagojik beceriler alt boyutunda yer alan maddelere ait faktör yük değerlerinin .574 ile .855 arasında; öğrenciye karşı yakın ilgi alt boyutunda yer alan maddelere ait faktör yük değerlerinin .719 ile .853 arasında değer aldığ tespit edilmiştir. Ölçeğin son faktörü olan köyde görev yapma alt boyutunda yer alan maddelerin ise faktör yük değerlerinin .562 ile .762 arasında değer aldığı görülmüştür. Ölçeğin alt boyutları arasında orta düzeyde, yönü pozitif olan ve anlamlı bir ilişkinin var olduğu ortaya konmuştur. Ölçeğin geneline yönelik iç tutarlık katsayısı değeri .906; Guttman değeri .809 ve Spearman-Brown katsayısı değeri ise .811 olarak hesaplanmıştır.

İkinci düzey doğrulayıcı faktör analizi bulguları uyum indeks değerlerinden $\mathrm{X}^{2} / \mathrm{sd}$, NFI, NNFI, CFI ve IFI uyum indekslerinin mükemmel uyum; RMR, RMSEA, SRMR, GFI, AGFI ve RFI uyum indekslerinin ise kabul edilebilir uyum düzeyinde olduğunu ortaya koymuştur. Madde toplam korelasyon değerlerinin .52 ile .91 arasında değer aldığı görülmektedir. Bu katsayılar her bir değişken ile gizil değişken arasındaki korelasyonu belirtmektedir. Korelasyon katsayısı ne kadar yüksek ise ilgili değişkenin gizil değişkeni açıklama oranı da o kadar yüksek olur. Bu bağlamda ölçek maddelerinin yüksek düzeyde bir korelasyon sergilediği ve hedeflenen özelliği ayırt etme bakımından uygun olduğu ifade edilebilir. Her bir ölçek maddesi için t değerlerinin anlamlı olduğu görülmüştür. Bu durum ilgili maddelerin aynı özelliği ölçmeye yönelik olmadığı yönünde bir kanıt oluşturmaktadır. Hem sınıf öğretmenlerinin görüşleri hem de alanyazın desteğinden hareketle geliştirilen sınıf öğretmenleri için özyeterlik inanç ölçeğinin geçerli, güvenilir ölçümler sunacağına ve alanyazına katkı sağlayacağına inanmaktayiz. 


\section{EK}

\section{Sınıf Öğretmenleri için Öğretmen Öz-Yeterlik İnanç Ölçeği (Türkçe Formu)}

Değerli katılımc1,

Bu ölçek sizlerin öğretmenlik mesleğine yönelik öz-yeterlik inanç düzeylerinizi tespit etmek amaciyla geliştirilmiştir. Ölçekte yer alan maddeleri dikkatlice okumanız ve sizi en iyi anlatan seçeneği işaretlemeniz veri güvenirliği bakımından önemli görülmektedir.

\begin{tabular}{|c|c|c|c|c|c|}
\hline MADDELER & 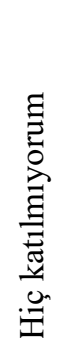 & 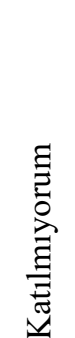 & 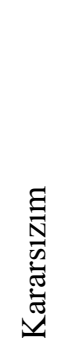 & 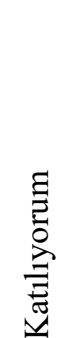 & 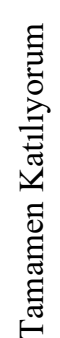 \\
\hline 1. Sinıf içerisinde meydana gelen her türlü problemle baş edebilirim. & (1) & (2) & (3) & (4) & $(5)$ \\
\hline 2. Öğretim faaliyetlerini, ögrencilerimin ihtiyaçlarına göre düzenleyebilirim. & (1) & $(2)$ & (3) & (4) & (5) \\
\hline 3. Öğretim teknolojilerini etkili bir şekilde kullanmakta güçlük yaşayabilirim. ** & (1) & $(2)$ & (3) & (4) & (5) \\
\hline 4. Meslektaşlarımla etkili bir iletişim kurup işbirliği içerisinde çalışabilirim. & (1) & (2) & (3) & (4) & (5) \\
\hline $\begin{array}{l}\text { 5. Beni en çok zorlayacak şeylerden biri veli ziyareti yapmak/velilerle iletişim } \\
\text { kurmaktır. } * *\end{array}$ & (1) & (2) & (3) & (4) & (5) \\
\hline 6. Meslek hayatımın sonuna kadar araştırmacı bir öğretmen kimliği tașıyabilirim. & (1) & (2) & (3) & (4) & (5) \\
\hline 7. Gerektiğinde öğrencimin elini tutup yazı yazdırabilirim. & (1) & $(2)$ & (3) & (4) & (5) \\
\hline 8. Öğrencilerimle birlikte oyun oynama düşüncesi beni kaygılandırıyor. ** & (1) & $(2)$ & (3) & (4) & (5) \\
\hline 9. Derslerimi öğrencilerimin ilgi ve merakları doğrultusunda planlayabilirim. & (1) & $(2)$ & (3) & (4) & (5) \\
\hline 10. Öğretim faaliyetlerine uygun yöntem ve teknik seçebilirim. & (1) & (2) & (3) & (4) & (5) \\
\hline 11. Etkili bir ölçme-değerlendirme yapabileceğime inanmıyorum. ** & (1) & $(2)$ & (3) & (4) & (5) \\
\hline 12. Gerektiğginde öğrencilerimin el ve yüz temizliğini yapabilirim. & (1) & $(2)$ & (3) & (4) & (5) \\
\hline 13. Öğrencilerim yaralandığında basit ilkyardım müdahalesinde bulunabilirim. & $(1)$ & $(2)$ & (3) & $(4)$ & $(5)$ \\
\hline $\begin{array}{l}\text { 14. Öğrencilerin montlarını giydirmek veya kıyafetlerini düzenlemek zorunda } \\
\text { kalmak beni zorlayabilir. ** }\end{array}$ & (1) & (2) & (3) & (4) & (5) \\
\hline $\begin{array}{l}\text { 15. Öğrencilerimin ders dışında elimi tutmalarını veya bana sarılmalarını normal } \\
\text { bir davranış olarak görürüm. }\end{array}$ & (1) & (2) & (3) & (4) & (5) \\
\hline 16. Birleştirilmiş sınıflı bir köy okulunda rahatlıkla görev yapabilirim. & (1) & $(2)$ & (3) & (4) & (5) \\
\hline $\begin{array}{l}\text { 17. Atandığım köyün altyapı ve ulaşım imkânlarının yetersiz olması beni } \\
\text { kaygılandırır. ** }\end{array}$ & (1) & (2) & (3) & (4) & (5) \\
\hline 18. Köy okuluna ait lojmanda kalabilirim. & (1) & $(2)$ & (3) & (4) & (5) \\
\hline 19. Okulda veya lojmanda, kimseden yardım almadan, soba yakabilirim. & (1) & $(2)$ & (3) & (4) & (5) \\
\hline
\end{tabular}

